\title{
Successful enucleation of radicular cyst after prophylaxis in a hereditary angioedema patient
}

\author{
Herediter anjioödemli bir hastada profilaksi sonrasında \\ radiküler kistin başarıyla çıkarılması
}

\author{
Ilkay Aydogdu, Gokten Bulut ${ }^{2}$, Asuman Erden Camyar², Nihal Mete Gokmen² \\ ${ }^{1}$ Dept. of Oral and Maxillofacial Surgery, Ege University School of Dentistry, Izmir, Turkey, ${ }^{2}$ Dept. of Internal Medicine, Ege University Faculty of \\ Medicine, Izmir, Turkey
}

\begin{abstract}
Hereditary angioedema (HAE) due to Cl-INH deficiency (Cl-INH-HAE) is an autosomal dominant inherited disease characterized by recurrent skin and mucosa swellings that commonly involve the extremities, intestines, face, genital area and upper airways. Dental procedures are important attack triggers in Cl-INH-HAE patients. Attacks following dental procedures are commonly localized to the face and larynx. Laryngeal edema can cause death by asphyxiation. A 48-year-old female patient was admitted to our hospital because of the excessive accumulation of calculus on the teeth which was noticed during routine dental examination. At the oral examination calcified dental plaque, bleeding by gingival probing, and discoloration of the teeth \#31-32 were detected. By radiographic and clinical findings radicular cyst pre-diagnosis was made, and it was decided to enucleate the cyst.However, the patient's medical history revealed that she was diagnosed with C1-INH-HAE at the age of 40. To prevent possible facial and laryngeal edema, 1000 units of $\mathrm{Cl}$ inhibitor concentration was given 1 hour before the procedure. Under local anesthesia, the lesion was totally enucleated with its capsule. The risk of having attack after tooth extraction is about $37.5 \%$ and nearly $1 / 3$ of these attacks are associated with laryngeal edema in patients with C1-INH-HAE. However, prophylaxis with $\mathrm{Cl}$ inhibitor concentration led to a $44.1 \%$ reduction in angioedema attacks on a per-patient basis. With this case, we wanted to draw attention to the importance of questioning the patient and his/her family for recurrent nonpruritic skin and mucosa swelling and abdominal pain attacks before surgical interventions to the mouth, neck, and throat area.
\end{abstract}

Key words: hereditary angioedema, C1 inhibitor prophylaxis, laryngeal edema

\section{O̊zet}

Herediter anjioödem Cl inhibitör protein eksikliğine bağlı gelişen, tekrarlayan, kaşıntısız, deri ve mukoza şişkinlikleri ile karakterize genellikle, ekstremiteleri, barsak mukozasını, yüzü, genital bölgeyi ve üst hava yollarını tutan otozomal dominant kalıtılan bir hastalıktır. Diş ve diş etine yapılan müdahaleler ile özellikle yüz ve üst solunum yollarına lokalize ataklar oluşabilmekte ve hayatı tehdit edici larinks ödemi gelişebilmektedir. 48 yaşındaki kadın hastanın rutin kontrolünde diş etlerinde anormal tartar birikimi olduğu görüldü. Radyolojik incelemede 31 ve 32 nolu dişlerin apikal köklerinde 2x15 mm boyutlarında radyolüsen lezyon saptandı. Radiküler kist ön tanısı ile kist enükleasyonu kararı verildi. Hastanın anamnezinde 40 yaşında herediter anjioödem tanısı konulduğu ve yılda 2 kez

Corresponding author: Nihal Mete Gokmen, Dept of Internal Medicine, Ege University Medical Faculty, Division of Allergy and Clinical Immunology, 35100, Bornova, Izmir, Turkiye, Phone: +90 23239035 03, E-mail: enihalmete@yahoo.com.tr

Received: 20 June 2019 Accepted: 27 June 2019

Conflict of Interest: None. 
abdominal ve/veya ekstremite atağı geliştirdiği öğrenildi. Yüzde ve larinkste gelişebilecek olası atağı önlemek amacı ile işlemden bir saat önce $\mathrm{Cl}$ inhibitör konsantresi 1000 ünite verildi. Lokal anestezi eşliğinde radiküler kist kapsülü ile birlikte çıkarıldı, patolojik incelemede kapsülün epitel hücresi ile çevrili olduğu ve bu bulgunun da tanıyla uyumlu olduğu görüldü. Hastamızda işlem sonrası atak oluşmadı. Herediter anjioödem hastalarında diş çekimi sonrası atak gelişme riski ortalama \%37.5'dur ve gelişen her 3 ataktan biri larinks bölgesini tutmaktadır. Diş çekimi sonrası gelişen ataklar işlemden ortalama 14.3 saat sonra ortaya çıar (en erken 1 saat en geç 72 saat). Cl inhibitör konsantresi ile yapılan profilaksi atak oluşumunu \%44 oranında azaltmaktadır. Yüz, ağız, boğaz bölgesine yapılacak cerrahi girişimler öncesinde hastanın tekrarlayan anjioödem ve karın ağrıları açısından sorgulanması gerekmektedir.

Anahtar kelimeler: herediter anjioödem, C1 inhibitör profilaksisi, laringeal ödem

\section{Introduction}

Hereditary angioedema (HAE) due to Cl-INH deficiency (C1-INH-HAE) is an autosomal dominant inherited disease characterized by recurrent skin and mucosa swellings that commonly involve the extremities, intestines, face, genital area and upper airways. ${ }^{1}$ C1-INH-HAE is resulting from a mutation of the SERPING1 gene encoding for Cl-INH. In Cl-INH-HAE, the reduced inhibitor effects of Cl-INH on plasma contact system leads to increased liberation of bradykinin from high-molecular-weight kininogen (HK). There are two types of Cl-INH-HAE; in type I mutations resulting in the production of truncated or misfolded proteins that are not secreted efficiently localized throughout the gene lead to low $\mathrm{Cl}$-INH concentrations and therefore low Cl-INH function, in type II mutations resulting in the production of the dysfunctional Cl-INH protein occur commonly at exon 8 that decode the reactive center and two critical hinge region lead to low C1-INH function despite normal levels of antigenic C1-INH. ${ }^{2}$ Dental procedures are important attack triggers in Cl-INHHAE patients. Attacks following dental procedures are commonly localized to the face and larynx. ${ }^{3}$ Laryngeal edema can cause death by asphyxiation. ${ }^{1}$

\section{Case report}

A 48-year-old female patient was admitted to our hospital because of the excessive accumulation of calculus on the teeth which was noticed during routine dental examination. At the oral examination calcified dental plaque, bleeding by gingival probing, and discoloration of the teeth \#31-32 were detected, however there was no periodontal pocket and teeth mobility. By radiographic examination a radiolucent lesion with a defined border of $2 \times 15 \mathrm{~mm}$ at the apical roots of teeth $\# 31$ and $\# 32$ was discovered (Fig. 1). In the electrical pulp test, teeth \#31 and \#32 were found to be devital. Patient had pre-existing root canal treatment on tooth \#32. Root canal treatment for tooth \#31 was recommended as soon as possible.

The region on the vestibular gingiva of teeth $\# 31$ and $\# 32$, was compatible with the radiological location of the lesion, could be fluctuated, and bone expansion was detected. All these findings led us to the pre-diagnosis of radicular cyst, and it was decided to enucleate the cyst. One week prior to the operation, the patient was trained in cleaning teeth and gums.

However, the patient's medical history revealed that she was diagnosed with Cl-INH-HAE at the age of 40 . Her diagnostic laboratory values were concordant with type I C1-INH-HAE with low levels of Cl-INH, $10 \mathrm{mg} / \mathrm{dL}$ (normal, 21-39 mg/dL); Cl-INH function, 18.3\% (normal, 70-130\%) and near normal C4, $10 \mathrm{mg} / \mathrm{dL}$ (normal, $10-40 \mathrm{mg} / \mathrm{dL}$ ) but normal Clq, $248 \mu \mathrm{g} / \mathrm{mL}$ (normal $100-300 \mu \mathrm{g} / \mathrm{mL}$ ). Her angioedema symptoms began at 27 years old and until now, she has usually experienced biannually peripheral angioedema attack, but just one genital edema attack and one abdominal attack but no facial or laryngeal attack.

The enucleation of cyst procedure was explained to the patient. To prevent possible facial and laryngeal edema, 1000 units of $\mathrm{Cl}$ inhibitor concentration, (Cinryze, Takeda, Switzerland) was given 1 hour before the procedure. $2 \%$ articaine HCL solution was used for local an- 


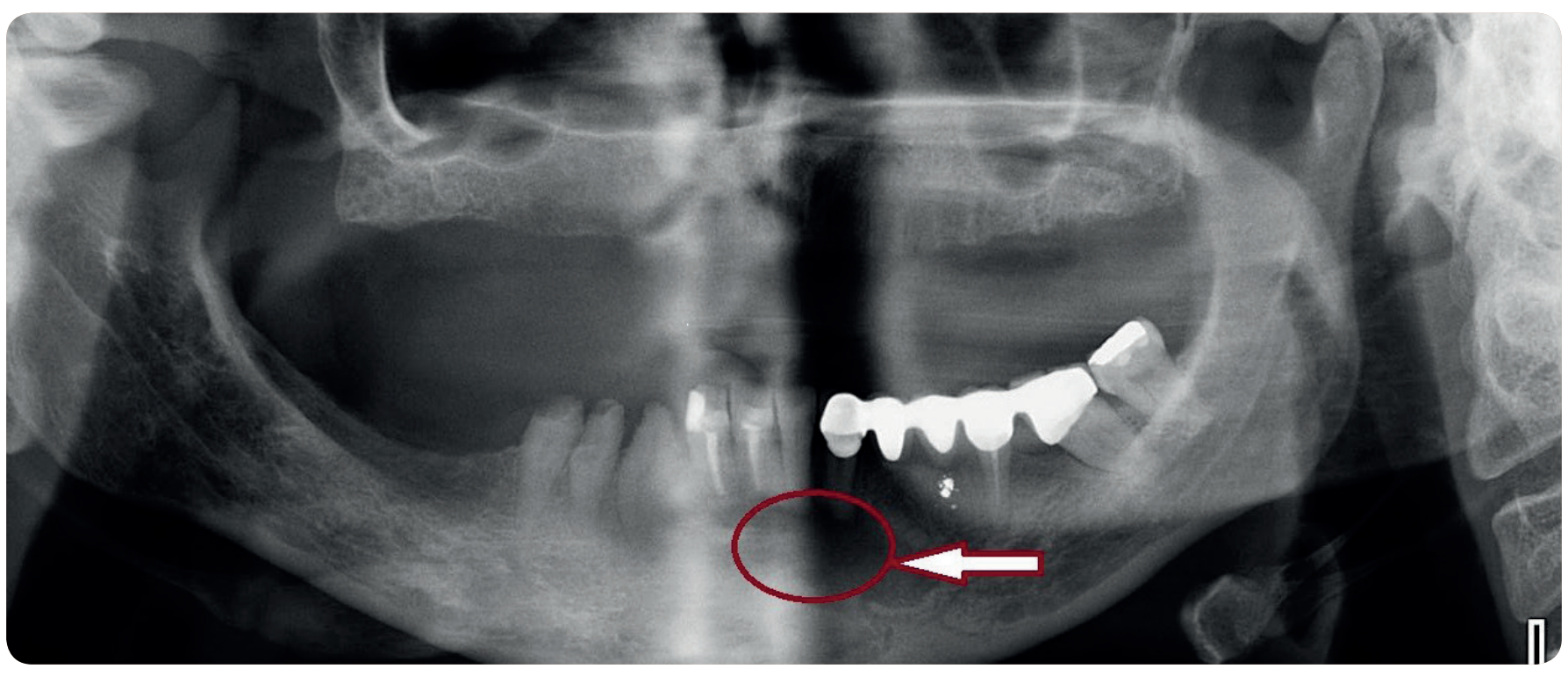

Fig. 1. The preoperative orthopantomograph radiograph showed large periapical radiolucency associated with teeth \#31-32

esthesia, and then the lesion was totally enucleated with its capsule and wound margins were primary closed. Radicular cysts are commonly paved with non-keratinized squamous epithelium. ${ }^{4}$ Compatible with this information postoperative histopathological examination revealed that the cyst capsule was covered with squamous epithelium. In the postoperative period, the patient was treated with amoxicillin/clavulanic acide 1000 $\mathrm{mg}$ bid and diclofenac potassium $50 \mathrm{mg}$ bid treatment for 7 days long. On the 7 th day, it was observed that the operation area improved in a healthy way and sutures were removed. Radiological follow-up was recommended every 3 months.

\section{Discussion}

Hereditary angioedema (HAE) is an important disease that dentist should have knowledge about; because surgical interventions to the mouth and throat area may trigger skin and mucosa swellings that bear the risk of laryngeal edema. ${ }^{3}$ Seven cases with fatal outcomes have been reported after tooth extraction in patients with HAE. ${ }^{5-7}$ However, not all dental surgery procedures, including tooth extraction, are followed by an acute attack. The risk of having attack after tooth extraction is about $37.5 \%$ and nearly $1 / 3$ of these attacks are associated with laryngeal edema. The mean time between tooth extraction sessions and the onset of symptoms was 14.3 hours (range 1-72 hours). ${ }^{3}$ In the literature, it has been reported that fresh frozen plasma, antifibrinolytics, attenuated androgens, and Cl-INH concentrate can be used in prophylaxis..$^{8-11}$ However HAE symptoms were reported despite prophylaxis in $20.8 \%$ patients. $^{3}$

Radicular cysts are inflammatory cysts of the jaws and are the most common form of odontogenic cysts. The progression of the caries cavity to pulp and formation of chronic inflammatory tissue can cause radicular cyst formation. Epithelial cell rests of Malassez are stimulated via several inflammatory mediators and cyst formation is started following degeneration of the cells in the center of the expanding epithelial tissue. Most of the radicular cysts are asymptomatic, however especially infected cysts can cause pain. ${ }^{4}$ In the literature, there are no reported cases of ClINH-HAE who underwent dental cyst enucleation. We successfully performed enucleation procedure via 1000 Unites Cl inhibitor concentrate prophylaxis therapy an hour prior. Because of no facial and laryngeal edema history of our patient, prophylaxis therapy may not be considered necessary. However, it was decided that prophylaxis should be performed since the risk of laryngeal edema increases especially after dental procedures and since the patient may have the first attack of laryngeal edema. On a per-pa- 
tient basis, prophylaxis with $\mathrm{Cl}$ inhibitor concentration led to a $44.1 \%$ reduction in angioedema attacks. ${ }^{3}$

With this case, we wanted to draw attention to the importance of questioning the patient and his/her family for recurrent nonpruritic skin, mucosa swelling and abdominal pain attacks before surgical interventions to the mouth and neck and throat area. Prophylaxis treatment of hereditary angioedema patients can prevent the risk of fatal laryngeal edema after dental intervention.

\section{References}

1. Longhurst H, Cicardi M. Hereditary angio-oedema. Lancet 2012;379:474-81.

2. Zuraw BL, Bernstein JA, Lang DM, et al. American Academy of Allergy, Asthma and Immunology; American College of Allergy, Asthma and Immunology. A focused parameter update: hereditary angioedema, acquired $\mathrm{Cl}$ inhibitor deficiency, and angiotensin-converting enzyme inhibitor-associated angioedema. J Allergy Clin Immunol 2013;131:1491-3.

3. Bork K, Hardt J, Staubach-Renz P, et al. Risk of laryngeal edema and facial swellings after tooth extraction in patients with hereditary angioedema with and without prophylaxis with $\mathrm{Cl}$ inhibitor concentrate: a retrospective study. Oral Surg Oral Med Oral Pathol Oral Radiol Endod 2011;112:58-64.

4. Martin L, PM Speight Odontogenic cysts: an update. Diagnostic Histopathology 2017;23:260-5.

5. Bork K, Barnstedt SE. Laryngeal edema and death from asphyxiation after tooth extraction in four patients with hereditary angioedema. J Am Dent Assoc 2003;134:1088-94.

6. Richards R, Crombie HM. Familial angioneurotic oedema: two fatal cases after dental extractions. BMJ 1960;2:1787.

7. Winnewisser J, Rossi M, Spath P, Burgi H. Type I hereditary angio-oedema. Variability of clinical presentation and course within two large kindreds. J Intern Med 1997;241:39-46.

8. Atkinson JC, Frank MM. Oral manifestations and dental management of patients with hereditary angioedema. J Oral Pathol Med 1991;20:139-42.

9. Sheffer AL, Fearon DT, Austen KF, Rosen FS. Tranexamic acid: preoperative prophylactic therapy for patients with hereditary angioneurotic edema. J Allergy Clin Immunol 1977;60:38-40.

10. Van Sickels NJ, Hunsaker RB, Van Sickels JE. Hereditary angioedema: treatment, management, and precautions in patients presenting for dental care. Oral Surg Oral Med Oral Pathol Oral Radiol Endod 2010;109:168-72.

11. Jaffe CJ, Atkinson JP, Gelfand JA, Frank MM. Hereditary angioedema: the use of fresh frozen plasma for prophylaxis in patients undergoing oral surgery. J Allergy Clin Immunol 1975;55:386-93. 